\title{
The Historicity of Peirce's Classification of the Sciences
}

\section{Chiara Ambrosio}

\section{(2) OpenEdition}

\section{Journals}

Electronic version

URL: http://journals.openedition.org/ejpap/625

DOI: 10.4000/ejpap.625

ISSN: 2036-4091

\section{Publisher}

Associazione Pragma

\section{Electronic reference}

Chiara Ambrosio, «The Historicity of Peirce's Classification of the Sciences », European Journal of Pragmatism and American Philosophy [Online], VIII-2 | 2016, Online since 17 January 2017, connection on 30 April 2019. URL : http://journals.openedition.org/ejpap/625; DOI : 10.4000/ejpap.625

This text was automatically generated on 30 April 2019.

\section{(c) $($ ) $(9)$}

Author retains copyright and grants the European Journal of Pragmatism and American Philosophy right of first publication with the work simultaneously licensed under a Creative Commons AttributionNonCommercial-NoDerivatives 4.0 International License. 


\title{
The Historicity of Peirce's Classification of the Sciences
}

\author{
Chiara Ambrosio
}

\section{AUTHOR'S NOTE}

I am grateful to Tullio Viola for the suggestion to participate in this much needed project on Pragmatism and the Writing of History. His enthusiasm, scholarly dedication and precious commentary genuinely helped this article come to life. A version of my initial thoughts on Peirce's classification of the sciences was presented at the Sixth Conference of the Society for Philosophy of Science in Practice at Rowan University. I am grateful to my co-panellists Matthew Lund, Jouni Matti Kuukkanen, Hasok Chang, as well as to the audience present at the session "In Pursuit of History: Philosophy of Science and the Practice of Historiography" for their lively and collegial comments on this work. Alex Csiszar kindly shared with me his thoughts on the classification of the sciences, as well as some precious chapters of his PhD thesis. My PhD student Claudia Cristalli read an early draft of this piece and provided extensive and thought-provoking comments, of the kind that made me question the direction of our supervisor-supervisee collaboration. Two anonymous referees provided invaluable suggestions to improve the quality of the arguments I present in this article, and I am deeply indebted to their constructive comments. Last but not least, Niall Le Mage put up once more with the domestic and emotional consequences of my obsession for Peirce. For this - and much more - I am grateful. A large part of this article was written in the summer 2016 at the Houghton Library in Harvard, in the days leading up to the results of the Brexit referendum. As an European academic based in the UK, I was deeply affected by the outcome of the vote. I sat outside Peirce's house in Cambridge on the day following the results, thinking that Peirce's Pragmaticist invitation to evaluate the conceivable consequences of adopting certain conceptions matters today more than ever. We are still a long way from releasing Peirce's pragmatic maxim from our ivory tower and letting it out in the world, and it is my hope that the theme of this special issue will be a first step in this direction. 


\section{Introduction}

Decoding and systematising Peirce's classification of the sciences has been a central concern for Peirce scholars. At least since Beverley Kent's landmark study Charles S. Peirce: Logic and the Classification of the Sciences (Kent 1987), Peirce's classification has been regarded as the key to solve some of the most complex puzzles surrounding his approach to logic, epistemology and metaphysics. From its relation to Peirce's 'architectonics' to its function in supporting his broader, thoroughgoing anti-foundationalism, from its crucial role in articulating and defining the limits and scope of the normative sciences to its interconnections with the development of the three categories, the classification of the sciences has been the backdrop against which scholars have tested their broader claims about the most fundamental aspects of Peirce's philosophy.

In this article, I want to explore the early life of Peirce's classification, and propose an alternative account of its role and function in Peirce's philosophical thought. More specifically, I want to suggest - somewhat controversially - that Peirce's classification of the sciences is characterised by a distinctive historicity, a feature that aligns Peirce's project with what Vincent Colapietro (1998: 129) has defined as the "historical thickness" of the Pragmatist outlook more broadly. I use 'historicity' in two complementary senses in the course of my discussion. On one hand, I aim to re-contextualise Peirce's classification and investigate it as a quintessentially nineteenth century pursuit. In doing this, I highlight a glaring limitation in the scholarship on Peirce - a limitation that is particularly evident in the case of the classification of the sciences, but has rippling effects on the ways in which Peirce's philosophy has been read and interpreted more broadly. Even the rare and isolated accounts that somehow place Peirce's classification in context (see for example Kent 1987: Ch. 2), do so in a distinctively internalist manner, thus segregating and separating Peirce's project from the hundreds of attempts at classifying the sciences that occupied the scientific community throughout the nineteenth century. Peirce himself, in a later note which will turn out to be quite important for my argument, admits to have examined "upward of a hundred attempts to classify the sciences" (R 1597: 5396 verso). Thus my first question - a question that Peirce scholars do not seem to have asked yet in regard to Peirce's classification - is: why would Peirce as a scientific practitioner and a philosopher, but most importantly as a historical actor in a precise historical context, worry about classifying the sciences?

3 The second sense in which I stress the historicity of Peirce's classification follows directly from the point I raised above. Establishing that Peirce's project did not develop in a void should lead us to consider the consequences of a historical account of his classification on its very content and systematisation. Here what I propose is to look at Peirce's project from the viewpoint of historical epistemology, and flesh out the contingent and contextual nature of his classification as well as the historical and dynamic approach that he develops, from his classification of the sciences, to the issue of classification more broadly. The classification of the sciences, in this sense, becomes a paradigmatic example of the importance of a historical reading of Peirce for the purpose of understanding Peirce's own historical works.

4 Historical epistemology, I will argue, casts new light on several characteristics that Peirce attributes to his classification. For example, it renders quite unsurprising the fact that Peirce insists on wanting to develop a 'natural' classification: he is certainly not alone in 
using this qualification, and an important line of inquiry consists precisely in spelling out how this characterisation relates to, or departs from, the widespread rhetoric around producing 'natural' classifications of the sciences in the nineteenth century.

5 An important part of my argument will revolve around an apparently curious detail that has remained so far unnoticed in the early history of Peirce's classification of the sciences. An early version of the classification appears as the preface to the first Lowell Lecture in the history of science, which Peirce delivered in the autumn of 1892 (R 1274a: 2). This is not a mere coincidence, I will argue, nor should it be taken as a simple historical curiosity. One of Peirce's main concerns is indeed to highlight the temporal dimension of his classification: the fact that classification is inevitably bound to the present state of science, at best "looking forward just a little" (R 1597: 5396 verso). As a preface to what would eventually become Peirce's larger project of a (never published) history of science, the classification of the sciences occupies a central methodological and historiographical function - one that is still of crucial importance to historical practice today: that of reminding the historian of the inescapable presentism that characterises the very starting point of historical inquiry. Examining this apparently puzzling consideration from the standpoint of historical epistemology, however, is a way of turning this aspect of Peirce's thought from a potential limitation to a historiographical strength. Peirce's placing a version of the classification of the sciences as the starting point of his history of science is a significant epistemic move aimed at recasting the function of classification as the (contingent) starting point of historical inquiry, and as the very "angle of vision" (Colapietro 1996: 137) that allows the historian to frame and refine her/his hypotheses about the past.

\section{Disciplining the Sciences in the Nineteenth Century}

The scholarship on Peirce's classification of the sciences usually concentrates on the form his classificatory system displayed in the early 1900s. Beverley Kent's discussion of the diagrammatic nature of Peirce's scheme, for example, takes the 1903 version of the classification as a turning point, labelling it as Peirce's 'perennial' classification (Kent 1987: 121ff). Douglas Anderson's (1995) examination of Peirce's classification similarly privileges the 1903 version, and investigates in particular the place of philosophy in Peirce's system. Helmut Pape (1993) focuses instead on the 1902 version, to show the relation between what Peirce defines as 'natural classes' and his account of final causes. More recently, Richard Atkins (2006) has proposed a critical comparison between the 1902 classification presented by Peirce in chapter 2 of the Minute Logic and the 1903 version contained in "An Outline Classification of the Sciences." His argument revolves around Peirce's mature formulation of the categories as a guiding classificatory principle, and shows that by 1903 Peirce realised that, along with being found in the sciences, "the categories may also be used to classify the sciences" (Atkins 2006: 484). This body of literature has cast substantial light on the metaphysical, epistemological and logical implications of Peirce's classificatory scheme. Questions such as the role of logic amongst the normative sciences, as well as its relation with mathematics (De Waal 2005) and its dependence on ethics (Legg 2014; Bellucci \& Pietarinen 2016), have taken centre stage and rightly so, as they form the core and the culmination of Peirce's mature philosophical system. 
7 Most of the accounts of Peirce's work on classification outlined so far, however, have as a primary focus the internal consistency of Peirce's scheme with key developments in his logic, epistemology and metaphysics. This also explains the emphasis on Peirce's 1902-1903 versions of the classification of the sciences: it is at this point that Peirce's phaneroscopy and his three categories mark an important development in his entire philosophy, with crucial consequences on his distinctive formulation of Pragmaticism (specifically renamed, and reframed, in opposition to James' version of Pragmatism). My account of Peirce's classification, on the other hand, starts from different, historical premises. My aim is not to argue against the achievements of Peirce's scholarship so far, nor do I want to propose a radically alternative interpretation of the development of Peirce's classificatory system. What I intend to point out, however, is a common omission in the literature, an omission that can be easily rectified by paying more attention to Peirce's place in the history of science. A historical approach, I contend, might hopefully open up new avenues of inquiry compatible with the current philosophical literature on the classification of the sciences. More specifically, I want to suggest the possibility that Peirce's work on and with the classification of the sciences was as much an effort toward internal consistency as it was a response to external constraints and pressures directly related to the social organization of the sciences in the nineteenth century. I hope to show that the classification of the sciences, far from being a philosophical pursuit conducted in isolation, is more productively investigated as Peirce's effort to balance and reconcile the internal consistency of his scheme with broader, external trends to reconfigure the sciences and their relationships as a conduit to social order.

The nineteenth century saw a proliferation of classifications of the sciences. From Jeremy Bentham to André-Marie Ampère, from William Whewell to August Comte, Herbert Spencer, Wilhelm Wundt and Karl Pearson (to name only a few figures well known to Peirce), classifying the sciences became a distinctive nineteenth-century pursuit and a scientific and philosophical genre in its own right. Arguably, attempts at mapping and ordering knowledge date at least as far back to Aristotle (a fact that Peirce himself recognises - see for instance $\mathrm{R} 1336$, a manuscript to which I shall return later). But in the nineteenth century, and specifically from the 1820 s onward, the pursuit of classifying the sciences acquired a distinctive epistemological significance in relation to the growing specialisation of science and the emergence of disciplines (Schaffer 2013). Most of the classifications of the time open with an attack to the traditional Baconian organisation of knowledge on the basis of the three faculties of memory, imagination and reason, as well as its legacy in the eighteenth century. "Such scales as those of Bacon and D'Alembert are constructed upon an arbitrary division of the faculties of the mind," wrote August Comte in presenting his own classification (Comte 1853: 18), pointing out their inadequacy to the present state of the positive sciences. Negotiating the relationship between the sciences in the nineteenth century was in line with broader efforts toward standardisation and the politics of scientific measurement, as well as with political discourses around the internationalisation of science and the need of communicating scientific results through an emergent international network of scientific periodicals. ${ }^{1}$ It is indeed rather odd that even historians of science have paid little attention to such a widespread trend in the nineteenth century. ${ }^{2}$ The most up-to-date study on this issue is an extensive discussion of the "classifying moment" in nineteenth-century science by Alex Csiszar (2010). Interestingly, Peirce features as a key player in his narrative - a detail I shall return to in the next sections. 
Csiszar (2010: 350ff) distinguishes two related aims behind the impulse to classify the sciences - a bureaucratic aim and an epistemic aim. Philosophical attempts to classify the sciences emerged in parallel to a more general reorganisation of scientific knowledge, one that was dictated by a growing bureaucratic need to survey and index all existing publications for a complete picture of the scientific landscape of the time. Led by the Royal Society in England, this proposal was as much a bibliographical exercise as it was an exercise in diplomacy: indeed, the Royal Society sought the collaboration of similar international institutions, such as the Académie des Sciences, the Smithsonian Institution and various German state academies. The First International Catalogue Conference, held in London in 1896, was the culmination of this international effort, with the launch of the International Catalogue of Scientific Literature in 1901. "During this period," Csiszar claims, "scientists, politicians and bibliographers became close collaborators and competitors in the race to classify the world's scientific literature" (Csiszar 2010: 352). This is the time in which Melvil Dewey's now famous decimal indexing system emerged as the golden international standard for the efficient organisation of offices and libraries (Csiszar 2010: 366); it is also a time when similar indexing projects were extended to the classification of people, as in the case of Alphonse Bertillon's system of index cards to classify criminals and Francis Galton's system to record and retrieve the fingerprints of repeat offenders (Sekula 1986; Csiszar 2013).

Toward the end of the nineteenth century, Csiszar argues, the bureaucratic need to survey the sciences merged with a distinctively epistemological urge to give a philosophical foundation to what thus far had been a quest for efficiency in international coordination. Indexes of the scientific literature were initially arranged in alphabetical order, but this was found inadequate for the purpose of classifying scientific knowledge. Finding a system of epistemological categories that would govern the relationships between the sciences became an essential task to legitimise philosophically the place and authority of science in nineteenth-century society. Mapping the current state of knowledge was ultimately aimed at producing an empirical image of science, in a movement that Csiszar interprets as simultaneously social and epistemological (Csiszar 2010: 370). It is at this point that bureaucratic classification joined forces with the proliferation of attempts at producing philosophical classifications of knowledge, guided by distinctive philosophical categories, that had emerged in philosophical discourse at the beginning of the nineteenth century.

The philosophical drive toward classification, at least in the first quarter of the nineteenth century, went hand in hand with educational reform. A version of the classification of the sciences appears in the fourth appendix of Bentham's Chrestomathia (1817), and it is specifically tailored to the 'useful knowledge' that Bentham's educational proposal was supposed to instigate in the British middle classes. ${ }^{3}$ In a long opening preamble to his classification, Bentham revises D'Alembert's 'Encyclopaedial Tree' from the Encyclopédie (modelled, unsurprisingly, on Bacon's classification) and reorganises the sciences on the basis of their utility. Mapping the current state of knowledge was for him also aimed at distilling which subjects qualified as most useful: knowledge of Latin and Greek, which Bentham himself mastered, was considered dispensable, for instance, whereas the natural sciences, mathematics and 'technology' ${ }^{14}$ were considered most fundamental. Bentham's Chrestomatic project was directly related, and indeed specifically tailored to his proposal for a monitorial school which would accommodate up to a thousand pupils at a time. Bentham's school, the educational version of his Panopticon , was planned so that older students would teach younger ones, in a system where 
everyone could monitor and be monitored (Bentham 1983: 104). The ultimate control would be in the hands of a single teacher-master. The monitorial system fulfilled perfectly Bentham's principle of maximising utility, being a way of saving time, money, and of increasing the "relative aptitude" of the pupils themselves (Bentham 1983: 102). In one of the most detailed studies of Bentham's Chrestomathia, Elissa Itzkin (1978) has shown that proposals for monitorial schools were popular in England well before Bentham's. They initially emerged as a measure to cope with the shortage of teachers and the increase of the population, but soon acquired a distinctive social purpose: to apply the division of labour to intellectual and educational life. "Like the steam engine or spinning machinery, [the monitorial school] diminishes labour and multiples work," wrote Andrew Bell, one of the initiators of the monitorial project, assimilating the enterprise to the construction of an "intellectual and moral engine" (Bell 1808: 36). ${ }^{5}$ It is therefore not a surprise that Bentham's classification of the sciences is aligned with criteria of utility and control that were inextricably related to the demands of a new industrial society. In several respects, Itzkin concludes, Bentham's envisaged school "was reminiscent of scenes from Dickens' Hard Times" (Itzkin 1978: 315).

Bentham died in 1832; only two years later, in an article in the Quarterly Review, William Whewell described the current scientific landscape as "a great empire falling to pieces" (Whewell 1834: 59). The image of science and its place in British culture was changing rapidly, and so was the role of the classification of the sciences. Whewell had coined the term 'scientist' in 1833 precisely as a remedy to the fragmentation of the 'commonwealth of science,' a concern he shared with the members of the newly-founded British Association. ${ }^{6}$ As Richard Yeo (1993) has pointed out, the early Victorian period was a time in which the social and intellectual conditions of science invited a public 'metascientific' reflection on its status as a distinctive form of knowledge. Whewell's classification of the sciences, published in the second volume of his Philosophy of the Inductive Sciences, is part of a much larger project, one aimed at securing the legitimacy of a field that was still strongly in competition with natural theology on one side, and the classics on the other. Famously conversant in all these fields, ${ }^{7}$ Whewell was uniquely positioned to serve as a mediator as well as an indefatigable advocate of the necessity of a distinctive space for science and a distinctive identity for its practitioners in society.

Whewell's classification is explicitly framed as following from his earlier History of the Inductive Sciences (1857 [1837]). Indeed, history is a central classificatory criterion, which allowed Whewell to differentiate his scheme from others primarily in light of its focus on a historicised notion of ideas:

The Classification thus obtained depends neither upon the faculties of the mind to which the separate parts of our knowledge owe their origins, nor upon the objects which each science contemplates, but upon a more natural and fundamental element; namely the Ideas which each science involves. (Whewell 1847: 278)

Ideas regulate and connect facts, and form a 'natural' foundation for reasoning in each science. To each fundamental idea or conception corresponds a particular science - thus for example the fundamental conception of Space corresponds to Geometry, which is then grouped by Whewell under the "Pure Mathematical Sciences" (see fig. 1). 
Fig. 1. Whewell's Classification of the sciences (1847: 281)

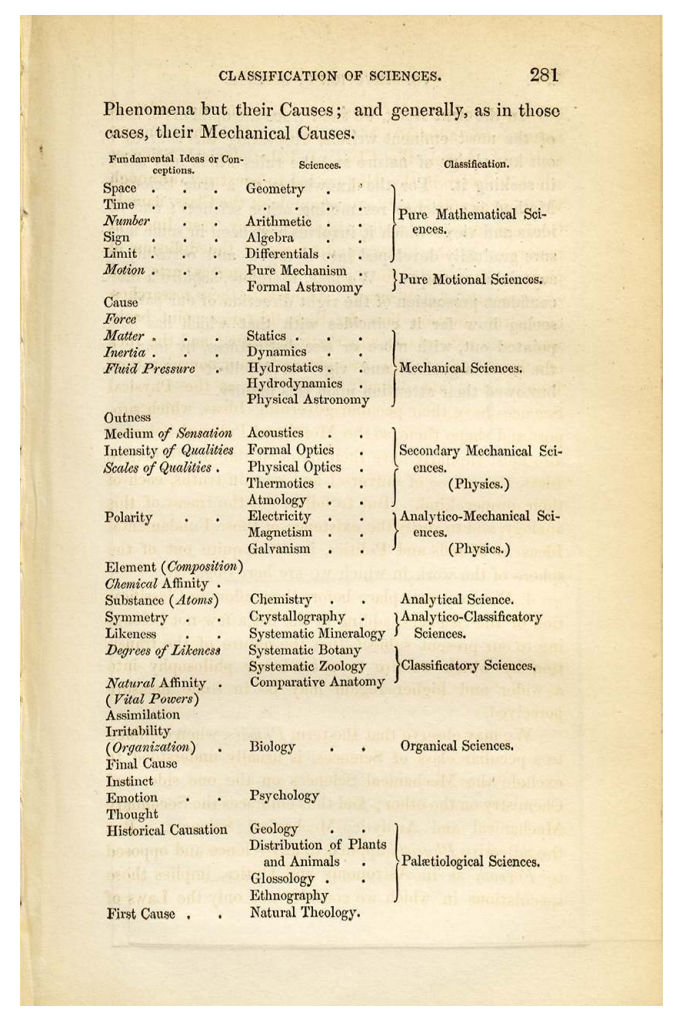

The British Library

By making his system 'naturally' led by ideas, rather than objects, Whewell also fulfilled another important aim: that of accounting for the diversity of what qualifies as a 'fundamental conception' for each science. His classification is thus profoundly antireductionist, in the sense that it aims at distilling the distinctive uniformity in which knowledge is achieved in each field. Thus, Whewell explains, it may be that the idea of Number, fundamental to the science of Arithmetic, is but a modification of the idea of Time; or the idea of Force is a modification of the idea of Cause. The purpose of classifying the sciences, however, is not to find an absolute measure for deciding which of these ideas or conceptions is more fundamental, and subsequently arrange the sciences on the basis of that absolute parameter. On the contrary - and here it becomes clear that 'natural' for Whewell is a qualification that aims to validate the distinctive identity of scientific practitioners - fundamental conceptions are contingent upon the specificities and needs of each science. This particular sense of 'natural' classification is one that Peirce will adopt and articulate in detail in his own classificatory system.

While British classifications reflected the emergence of specialisation and the concerns arising from the division of industrial labour, the politics of the French system were closely aligned with the aftermath of the Napoleonic era. The end of the empire in 1815 saw Paris reawakening to literary and philosophical influences, especially German Romanticism, which had been heavily censored under Napoleon. Power remained centralised in the capital, which also became a node at the intersection between literary and philosophical movements, social reform and industrial and technological developments. It is in this context that André-Marie Ampère and Auguste Comte 
developed their own classifications of the sciences, two examples of the distinctive form that the interaction between philosophy and science took in the French national context.

Ampère's classification formed a central part of his two-volume Essai sur la Philosophie des Sciences (1834-1843). He regarded the Essai as the culmination of his work as a scientist as well as a philosopher, and indeed his classification reflects more broadly his strong Kantian commitments. Here the sciences are classified on the basis of the opposition between world and mind: the most fundamental distinction Ampère outlines is between sciences cosmologiques, or cosmological sciences, engaged in the study of the material world, and sciences noologiques, or sciences of the 'understanding' (Ampère 1834: 28). Each of these realms was then further divided in sous-règnes and embranchemens: the subrealms of cosmological science, for example, were 'proper cosmology,' which branched out into mathematics and physics, and 'physiology,' which branched out into natural and medical physiology. Each branch was subsequently divided into sub-embranchemens and then sciences of 'the first order': for example, arithmetic and geometry were sciences of the first order deriving from the sub-embranchement of mathematics 'properly construed' (see fig. 2). Lastly, first order sciences were even further distinguished into second and third order sciences: arithmetical analysis, for example, was classified as a third order science deriving from the science of elementary arithmetic.

Fig. 2. André-Marie Ampère (1834), Classification des Connaissances Humaines, in appendix to the Essai sur la Philosophie des Sciences

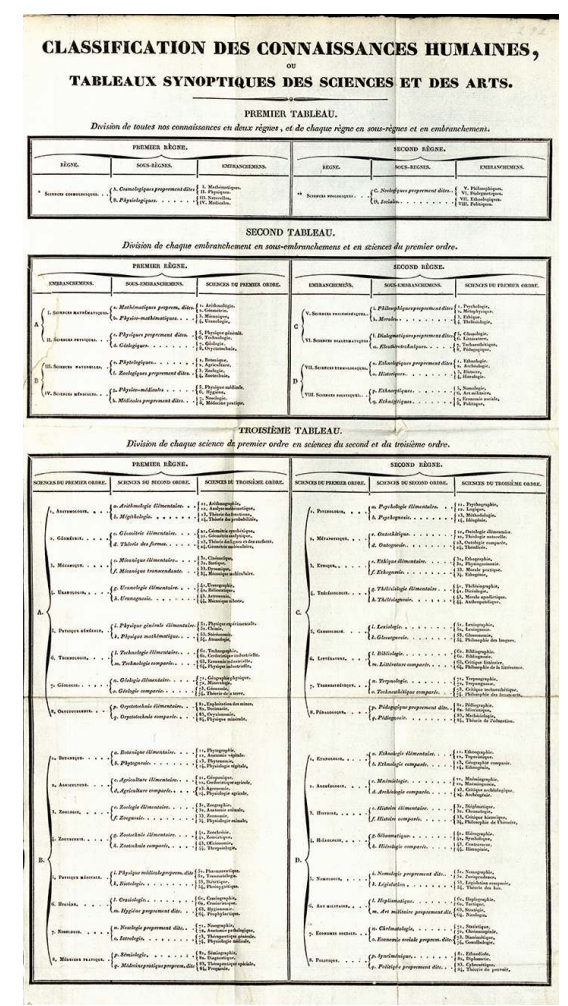

The British Library

In one of the very few detailed studies of Ampère's classification, John Tresch (2012) shows how the system outlined in the Essai is itself the culmination of Ampère's longstanding reflections on the unity of nature. Tresch reverts the standard image of Ampère's scientific research on electromagnetism as a triumph of empiricism and reason, 
and relates it instead to his immersion in German Naturphilosophie, which he absorbed primarily via the electromagnetic research of Hans Christian Oersted, as well as the unity of mind and nature outlined in Friedrich Schelling's philosophy of nature. While Ampère did maintain the distinction between mind and matter in his research on electromagnetism (and to a certain extent this distinction remains visible through his separation between sciences cosmologiques and sciences noologiques in his classification), Tresch shows that he simultaneously built an "activist epistemology" (Tresch 2012: 54) that served as a bridge between empiricist and romantic ideals. "The conceptual malleability and ubiquity of the 'cosmic substance' of electricity," Tresch claims, "made it analogous to his efforts to form a classificatory system that would contain the entire cosmos: a single taxonomy uniting all fields of knowledge" (Tresch 2012: 32). The theme of unity - unity of the sciences as well as unity of nature - is absolutely central to a range of efforts to classify the sciences in the nineteenth century, and will play a crucial role in Peirce's own system.

20 The strongest influence on Peirce's classification of the sciences was Comte's scheme, famously presented in the Cours de Philosophie Positive (1830-1842). ${ }^{8}$ Overshadowed by the neo-positivism of the 1920s (a movement that never quite expressed a precise position regarding its relationship with Comte's positivism, perhaps because it did not quite have one), ${ }^{9}$ Comte's philosophy is only recently enjoying a revival. The most striking aspect of his original formulation of positivism is the marriage of positive philosophy and positive polity: his contributions to philosophy of science cannot be fully appreciated unless they are placed in relation to his ideas about social and political reform. In a similar vein, the Comtean classification of the sciences, far from being a reductionist attempt at grounding sociology in the natural sciences, was part of a broader project of educational reform specifically aiming to oppose the intellectual division of labour, at the same time doing justice to the increasing complexity of the sciences in their relation to each other (Bourdeau 2015, np). Thus understood, the pursuit of classifying the sciences was for Comte an explicit response to the apparent fragmentation of the scientific landscape of his time, in a manner that renders his work quite close in spirit and aims to Whewell's.

21 Comte saw his classification of the sciences as a development of his law of the three stages. His key idea was that the development of human thought was marked by three successive stages: the theological - where the final causes of phenomena are explained by an appeal to the supernatural; the metaphysical - a transitory stage where the appeal to the supernatural is replaced by an appeal to abstract entities; and finally the positive stage - where the mind refrains from looking for ultimate causes and limits itself to the observation and description of the laws and regularities that govern nature. "What is now understood when we speak of an explanation of facts," Comte maintains, "is simply the establishment of a connection between single phenomena and some general facts, the number of which continually diminishes with the progress of science" (Comte 1853: 2). ${ }^{10}$ While the three stages marked - dynamically - the progress of the human intellect in the constitution of the sciences, the classification offered a picture of their order, which also served to recapitulate their dynamic progress (Pickering 1993: 203).

Comte's classification placed the sciences on a ladder in order of abstractness or generality (as I will show later on, this was a contentious point, which triggered a heated polemic with Herbert Spencer). It started from mathematics, the most abstract of the sciences, and continued with astronomy, physics, chemistry, biology and social physics or sociology. More concrete sciences depended on more abstract ones, but for Comte this did 
not entail a form of reductionism (or materialism, as he referred to it). The way Comte justified his anti-reductionist standpoint with respect to the relationship between the sciences was by underlining their irreducible diversity, but also through an explicit appeal to history, which he regarded as the primary method to conduct the positive science of sociology. On one hand, he clearly specified that each of the sciences in his scheme was characterised by distinctive objects, concepts and methods. On the other, while the tendency toward reductionism might appear itself historically motivated by the sciences capitalising on each other's findings, Comte maintained that this was counterbalanced by each science resisting invasion in order to secure and maintain the distinctiveness of its subject matter (Bourdeau 2015).

The most adamant critic of Comte's classification at the time was the British biologist and philosopher Herbert Spencer. Comte and Spencer's classifications have been regarded as complementary attempts at generating a 'grand synthesis' of knowledge, in a tradition that dates back at least to George Sarton's tribute to Spencer, written for the centenary of his birth (Sarton 1920). But Spencer himself also spent most of his later career distancing his own philosophy from Comte's positivism, and the classification of the sciences became the contentious ground over which he fought this intellectual battle. ${ }^{11}$ The essay The Classification of the Sciences, to Which are Added Reasons for Dissenting from the Philosophy of M. Comte (1864) outlines in detail the main points of Spencer's disagreement with Comte. A contentious issue, for Spencer, was the supposed linearity of Comte's classification. Spencer found Comte's ladder artificial and arbitrary: its serial arrangement of the sciences offered no evidence of the natural relationship of filiation between them. This was already outlined in Spencer's 1854 essay "The Genesis of Science," in the course of a long digression on Comte's classification. The Classification of the Sciences took up Spencer's earlier criticism and supplemented it with additional arguments and an alternative classificatory system. A 'true' classification, Spencer explains, should be based on likenesses amongst the objects grouped in each class: "If [...] the Sciences admit of classification at all" Spencer explains, "it must be by grouping together the like and separating the unlike" (Spencer 1864: 4). 'Like' and 'unlike,' in turn, are defined in terms of 'essential attributes' shared by the members of a certain class, in a quasi-essentialist argument about classification:

For things that possess the greatest number of attributes in common, are things that possess in common those essential attributes on which the rest depend; and, conversely, the possession in common of the essential attributes implies the possession in common of the greatest number of attributes. (Spencer 1864: 4)

An immediately related criticism is that Comte uses interchangeably 'abstractness' and 'generality' in his discussion of the organisation of the sciences. For Spencer this is evidence of the fact that Comte's classification arranged the sciences in a purely subjective, artificial order: "Abstractness is detachment from particular cases," whereas "generality means manifestation in numerous cases" (Spencer 1864: 7). In conflating the two, Spencer argued, Comte neglects the fact that abstraction requires paying attention to essential attributes, separated from "the phenomena which disguise [them]" (Spencer 1864: 7). In open response to Comte's supposed conflation, Spencer used 'degrees of abstraction,' thus redefined, as the fundamental criterion for his reorganisation of the sciences. Thus, 'Abstract sciences' deal with the forms in which phenomena are known to us: these are logic and mathematics. 'Abstract-concrete' sciences treat phenomena themselves in their elements - they "generalise the laws of relation which different modes of Matter and Motion conform to" (Spencer 1864: 14). Physics, mechanics, 
chemistry fall within this second class. Lastly, entirely concrete sciences treat phenomena themselves in their totalities: "the subject-matter of these Concrete Sciences is the Real, as contrasted with the wholly or partially ideal" (Spencer 1864: 18). Astronomy, geology, biology, psychology and sociology are all concrete sciences in this sense.

The Comte-Spencer controversy is indicative of the many issues at stake in the debate around the classification of the sciences in the second half of the nineteenth century. What is often portrayed as a clash of characters - a then already profoundly spiritual Comte, not particularly receptive to Spencer's criticisms, versus a stubborn Spencer, irritated by the constant references to Comte in reviews and reactions to his work, even by his close friends George Eliot and George Henry Lewes - was in earnest a clash of worldviews on how science should be conducted. This aspect of the debate emerges in a particularly forceful way in a letter from Spencer to Lewes, himself a persistent advocate of the commonalities between the two philosophers:

What is Comte's professed aim? To give a coherent account of the progress of human conceptions. What is my aim? To give a coherent account of the progress of the external world. Comte proposes to describe the necessary, and the actual, filiation of the ideas. I propose to describe the necessary, and actual, filiation of things. Comte professes to interpret the genesis of our knowledge of nature. My aim is to interpret, as far as possible, the genesis of the phenomena which constitute nature. The one end is subjective. The other is objective. (Spencer 1904: 570)

Where Spencer saw his classification as an objective matter, in alignment with the order of nature, Comte's system assumed the limitations of human knowledge as the starting point - and defining characteristic - of any attempt to systematise the sciences. Indeed, by arranging the sciences on a scale of increasing complexity, Comte aimed to reconnect general phenomena (as those studied by astronomy) with the variability and complexity of phenomena that were closer to humans, as those studied by sociology.

Yet, interpreting Comte and Spencer's classifications exclusively as a standard instance of the scientific polarisation around the categories of objectivity and subjectivity will not do full justice to what they, along with Bentham, Whewell, Ampère, and many other nineteenth-century classifiers (including Peirce!) were trying to achieve with their classifications. The appeal to objectivity in defence of the superiority of a particular classificatory system, well exemplified here by Spencer's curt statement, is a rhetorical gesture that needs to be contextualised in the broader conceptual and cultural space of nineteenth-century attempts at coordinating knowledge more broadly. These attempts were at once social and epistemological, and ultimately converged into what Lorraine Daston and Peter Galison (2009) have characterised as the image of 'a many-headed knower': the kind of scientific self emerging from the realisation of the distinctively collective nature of scientific objectivity as a virtue and a guide to the scientific enterprise. "This is a problem of the division of labour and the multiplication of knowers" Daston and Galison claim, "akin to any other such problem in the organisation of work: how to analyse a complex inquiry into modular parts, finding willing and able hands to undertake each part, and efficiently integrate the results" (Daston \& Galison 2009: 297). Among the examples of this impulse toward coordination they refer to the Internationale Grandmessung, an attempt at a complete measurement of the shape and dimensions of the Earth - a grandiose project to which Peirce himself contributed while employed at the US Geodetic and Coast Survey. Nineteenth-century classifications of the sciences add an additional layer to the picture about coordination provided by Daston and Galison, as 
they offer a 'many-headed rationale' for adjudicating how labour should be divided without compromising the fundamental unity of the scientific enterprise, and a clear view that this process of adjudication was primarily marked by irreducible disagreements of the kind that saw Spencer against Comte, or Whewell against Bentham's utilitarianism. Fighting over the superiority of a classification was as much an epistemological, metascientific matter, as it was a statement about the national and international politics of science, and who should be allowed to enter that debate. Peirce joined this discussion relatively late, but it is precisely for this reason, I claim, that his classification demands to be reconnected to the broader external context in which it was produced - a context in which he played the role of witness as well as that of a directly involved practitioner.

\section{Peirce's Classification, c1892}

My own classification is a direct reformation of that of Comte. I imitate Comte in making chemistry follow directly after general physics, as a specialization of it, in making biology a specialization of chemistry, but on a ground that was not understood at Comte's time, namely that biology is merely an account of the properties of protoplasm which is a class of chemical substances. I also imitate Comte in making sciences of organizations and organisms follow after sciences of classifications of individuals. But I separate from Comte, in making pure mathematics a science, in making philosophy a science, in recognizing the psychical sciences as a series parallel to the physical sciences, in recognizing the descriptive sciences in general, and not merely astronomy, and in transposing them from the first to the last place and in recognizing the practical sciences. ( $R 1336$ c1892: 4)

Thus Peirce characterised his project of compiling a classification of the sciences, in a manuscript entitled "Philosophy in Light of the Logic of Relatives" (c1892). The manuscript, briefly discussed by Kent (1987), is by no means his earliest attempt at classifying the sciences. ${ }^{12}$ Kent dismisses it rather quickly, qualifying it as one of the several instances in which Peirce reflects on the place of philosophy in his classification, and concluding that it offers evidence of how "exhibiting the relations of a given science to various other sciences indicates some of the conceivable effects of that science" (Kent 1987: 52). Hidden between the lines, however, there is a far broader set of claims advanced by Peirce in this particular piece of writing, claims that are not in contradiction with the pragmaticist relevance - that is, the 'conceivable effects' - of singling out the role of philosophy amongst the sciences.

I want to argue that this manuscript is important in the context of Peirce's classification, partly because it is one of the instances in which Peirce openly discusses the relationship of his proposed system to Comte's, but primarily because the rhetorical strategy he pursues in articulating such relationship is a clear attempt at positioning himself, as a philosopher and as a scientist, within the broader late nineteenth-century philosophical and institutional debate around the status and current shape of scientific knowledge. "It is incumbent upon every philosopher in order to make himself understood," Peirce states only a few lines earlier, "to explain in what way he came up with his ideas. For we must all submit to be classified and ultimately to be pigeon-holed" (R1336: 3). This is an initial indication of a point that has been overlooked in the literature on Peirce's classification: Peirce is here using his classification of the sciences as a form of 'currency' to secure his identity and status in the very community of classifiers to which he is offering his contribution. He also shows to be well aware that offering a classification is itself a 
pathway toward being pigeon-holed: along with their objects, classifications classify classifiers. Peirce's statement, however, does not imply an absolute inevitability in this process: by making his commitments explicit (however rhetorically coated they may be, or perhaps precisely via this rhetorical move), he is steering the recipients of his classification toward including him into a particular pigeon-hole rather than others. This becomes even clearer a few lines later where, for example, he takes a precise position in the Spencer-Comte dispute: "Herbert Spencer attempted to reform Comte's classification, but in my opinion not with sufficient power to repay study" (R1336: 4).

Contrary to Spencer, Peirce finds Comte's idea that the sciences should be classified according to their degrees of abstractness sound and quite unproblematic. He does not dwell upon the distinction between abstractness and generality, but this may be because the distinction for Spencer was an opportunity to advance a quasi-essentialist view of classification, which Peirce did not endorse. ${ }^{13}$ Peirce reads Comte's emphasis on 'degrees of abstractness' in a distinctively differential way:

We desire to have our classification as significant as possible. That is to say, we desire that, over and above, those characters of the different classes of science which serve to delimit them and to discriminate from one another, they should have as many interesting extra points of distinction as possible; for the value of a classification lies precisely in that. (R1336: 5-6)

31 A classification of the sciences should be 'significant' first and foremost to scientific practitioners. It should reflect differences, rather than similarities, between diverse fields of inquiry, for it is through difference that each field defines and delimits itself. As I will show later on in this section, here Peirce starts articulating a point that will become essential to his subsequent definition of a 'natural' classification: the fact that a significant classification should reflect the order of, and relations between, the various sub-communities that constitute science. Peirce expands on this point even further:
We find the different sciences are separated to a great extent into different circles of men who have comparatively little intercourse with one another. What makes the specialist of one of these circles more competent to conduct certain inquiries than a man not in that circle is that he is trained to that sort of inquiry, and especially that he is competent to make a kind of observation that ordinary men cannot make. He has the necessary apparatus and the necessary experience. Hence it is that sciences are separated from one another largely by virtue of the different kinds of observations upon which they are based. (R1336: 6)

What Peirce is articulating here is precisely what Csiszar (2010: 370) defined as an attempt at delineating an 'empirical' image of science, typical of nineteenth century classifications. As practices and practitioners form the empirical content of a classification of the sciences, it is to these that Peirce directs his attention. He singles out observation as the discriminating factor not only to distinguish the sciences from each other, but also to demarcate science from non-science. In stating that scientists are 'competent to make a kind of observation that ordinary men cannot make,' however, he is not unquestioningly attributing authority to the field. Instead, he proposes that the justification for the distinctive epistemic position attributed to science is to be found in the extensive training that scientific practitioners must undergo in order to earn their access to the community to which they aim to contribute. "Those who do not make a given kind of observations," Peirce continues, "are segregated from those who do; and this segregation tends to encourage the growth of different sets of ideas, and those different sets of ideas will give special characters to methods of study and to the truths they discover" (R1336: 6). Scientists have a privileged perspective upon a certain range of 
phenomena only insofar as they train themselves and each other to observe in particular ways. This in turn is shaped by, and shapes, the conceptual and methodological direction that different kinds of scientific inquiry take. The 'segregation' that Peirce mentions in his statement is not a shortcoming of the specialisation of observation, but a crucially enabling factor that allows different sets of ideas to grow. Peirce's emphasis on observation is thus clearly different from the 'received view' of positivism, a view he did not endorse, even though he was familiar with its most sophisticated forms. However sophisticated Comte's account of observation might have been (see Laudan 1971), for example, his version of positivism featured observation as antithetical to metaphysics: indeed the transition from the metaphysical to the positive stage was characterised for Comte by a renewed role for the observational component of science as the precondition to the identification and description of regularities in nature. Peirce, on the contrary, saw observation and metaphysics as complementary, insofar as metaphysics was construed itself as a science and conducted via experiment and reasoning (Haack 2007).

The contrast with positivist accounts of observation is visible in other writings by Peirce, roughly contemporary to the discussion of the classification of the sciences contained in R1336. An illuminating example is a passage from the "Reply to the Necessitarians" (1893),$^{14}$ which includes a targeted response to Paul Carus' claim that Peirce's logic of science appears to be articulated in a positivistic spirit (CP 6.404). Peirce's reply to Carus' charge starts with a tongue-in-cheek statement about where his supposedly 'positivistic' influences might have come from, and ends with an appeal to history that turns Carus' statement on its head:

Were I to name those of my teachers who were most positivistic in theory a smile would be excited. My own historical studies, which have been somewhat minutely critical, have, on the whole, confirmed the views of Whewell, the only man of philosophical power conjoined with scientific training who had made a comprehensive survey of the whole course of science, that progress in science depends upon the observation of the right facts by minds furnished with appropriate ideas. (R1336: 6; emphasis in the original)

Here Peirce is referring to Whewell's classification of the sciences, and specifically to the view that ideas are the guiding principle of classification. Just like in the case of the organisation of the sciences, ideas offer a 'natural' guiding rationale for what should be deemed worthy of attention and selection by a community of inquirers. This is reminiscent of a version of what philosophers of science, following Norwood Russell Hanson (1958), would now define as the 'theory-ladenness of observation'; however, Peirce's account is both broader and richer. ${ }^{15} \mathrm{~A}$ clarification of the sense in which Peirce construes observation emerges, for example, in his 1898 lecture on "The First Rule of Logic." This particular passage is revealing because here Peirce treats the role of observation in the context of a discussion of Whewell's account of induction and its differences from retroduction:

For what is observation? What is experience? It is the enforced element in the history of our lives. It is that which we are conscious of by an occult force residing in an object which we contemplate. The act of observation is the deliberate yielding of ourselves to that force majeure, - an early surrender at discretion, due to our foreseeing that we must, whatever we do, be borne down by that power, at last. Now the surrender which we make in retroduction is a surrender to the insistence of an idea. (EP2: 47) it as an add-on, but is built into it. Thus, the factual component of observation ('the 
enforced element in the history of our lives') is not separate from the ideas that lend observation an element of generality. ${ }^{16}$ In referring to Whewell's appeal to ideas, Peirce is therefore also accounting for the deep historicity that characterises modes and methods of observation within a particular community. For a fundamental consequence of building ideas into a theory of observation is that, construed in this way, observation becomes itself an inferential and semiotic process that unfolds through time. Interestingly, this aspect of Peirce's account emerges far more clearly from passages in which he outlines his disagreements with Whewell, which deserve a brief digression.

One point on which Whewell should be corrected, Peirce explains in a manuscript written for one of his 1892 Lowell lectures on the history of science, is that he remains hopelessly vague on "the mode of origination of these "appropriate ideas"' (R1274a: 5):

Whewell would say they spring from the nature of the mind. But the nature of the mind is something itself due to an evolutionary process; and we want to know just how these ideas came to be implemented in the nature of the mind. Besides, these ideas have most of them grown up during the course of scientific history, and we want to know just how they have grown up and under what general agency. (R1274a: 5)

What attracted Peirce to Whewell's views on science was that, along with their explicit emphasis on history, they ran against the dominant 'vulgarisation' of Baconian empiricism which was dominant in nineteenth century America. ${ }^{17}$ As Peter Novick explains: "to the great majority of American philosophers and scientists Baconianism meant in the first place a rigidly empirical approach: 'observations' were sacred" (Novick 1988: 34). This was accompanied by a meticulous avoidance of hypotheses: "it was unscientific to go beyond what could be directly observed, to 'anticipate nature"' (Novick 1988: 34). What Peirce found in Whewell was an alternative to this rather crude form of empiricism, one in which the chaos of empirical facts could be made meaningful through the imposition of general ideas upon those facts. On the other hand, however, Peirce points out that what Whewell seems to ignore is that ideas themselves undergo a process of refinement and growth: the iterative complementarity of ideas and observations is at the very basis of the historicity of both. "Whewell's theory in its general statement," Peirce claims in the same manuscript, "is that to make a scientific discovery two things are needful, $1^{\text {st }}$, facts drawn from without, and $2^{\text {nd }}$ ideas drawn from within, appropriate to the interpretation of those facts" (R1274a: 3). Whewell falls into the trap of separating (external) observed facts from (internal) ideas, with the result of relegating observation to a passive, subordinate affair. This has the paradoxical effect of rendering his approach (at least to observation) remarkably close to the 'vulgarisation' of Baconian empiricism which he purported to reject. Stating that ideas 'grow' is for Peirce at the same time a way of avoiding the intuitionist connotations which he saw as implied in Whewell's views, ${ }^{18}$ and at the same time proposing a richer sense of observation, as consisting of an active process of judgment and as a central part of the self-corrective nature of science. Indeed, his critique of Whewell continues with a biological analogy, which clarifies even further the distinctive historicity and complementarity of ideas and observations thus construed:

One of the great questions in biology is whether acquired characters are ever transmitted. If we speak of acquired mental and moral qualities, it is the question of whether training is of any use except to the individual. Whether, for instance, the conception of space is a pure result of breeding that is of the survival of those who possessed it early at birth, or whether it is in some measure the result of the inheritance of the intellectual earnings of our forefathers. No direct investigation 
can afford a satisfactory answer to this question. It can only be resolved by studying out the general modus operandi of intellectual development. (R1276a: 5-6) 'training' (which is of paramount importance for Peirce's classification of the sciences) as the contentious middle-ground between biologically and intellectually acquired characters. Along with a useful example, the reference to 'training' here invokes skills and habits that are developed and cultivated through observation as a primary vehicle of 'the intellectual earnings of our forefathers'. A direct investigation of our biological characteristics, Peirce remarks, will not set the balance between elements drawn 'from without' and elements drawn 'from within,' because that line is by its very nature blurred. The only way to answer the question, Peirce continues, is via historical inquiry:

One thing, as it seems to me, the history of science renders abundantly clear, it is that man's native, or natural and apparently innate ideas in the early stages of intellectual development, were far from being accurately true. They have to be subjected to a process of correction. (R1276a: 6-7, emphasis mine)

What Whewell took to be 'natural' or 'innate' ideas are themselves constantly evolving and as I will show below this adds a central tile to the puzzle of Peirce's definition of a 'natural' classification of the sciences, too. Ideas grow as they are enriched and corrected by observations, just as much as observations are by their very nature imbued with ideas.

The complementarity of ideas and observation is an important point where Peirce's philosophy crosses paths with the tradition of historical epistemology, a tradition to which he has been thus far associated only very loosely and in indirect ways. The reference to Whewell's historical works (even in the form of Peirce's criticism to his account of ideas) is particularly relevant here, as it shows that Peirce recognised the value of scientific observation as a historically located practice and as a mode of inquiry worthy of investigation in its own right. This is a theme that has been revived only recently in the history and philosophy of science, precisely by scholars working within the framework of historical epistemology (Daston 2008; Daston \& Lunbeck 2011). Lorraine Daston's idea of 'collective empiricism,' for example, offers an account of observation as a practice that was highly discussed and theorised by scientific practitioners at least since the seventeenth century, to the point that it became a scientific genre with its own distinctive connotations and methodological guidelines. "Even when observation was demoted to the status of handmaiden to experiment in mid-nineteenth century philosophy of science" Daston points out, "it continued to be a fundamental scientific practice - and arguably the one most likely to generate novelties, including new ontologies" (Daston 2008: 102). This reformulation of observation, constructed as an active way of "furnishing the universe" (Daston 2008: 100) with new ontologies, is what Peirce is drawing from Whewell and applying to his own characterisation of the practices and methods of delimiting the scope and boundaries of the sciences. More importantly, Peirce's criticism of Whewell points to a distinctive conceptual preoccupation that renders his work particularly relevant for contemporary debates in historical epistemology. In separating ideas 'from within' and observations 'from without' Whewell seems to display (admittedly in a peculiarly counterintuitive way) some of the traits that would characterise the later, post-Kantian separation between (subjective) knowers and (objective) world. As Daston points out, the quest for a neutral observation language, or (before that distinctive development in the twentieth century) the construction of observation as a mere registration of sense data "were Kantian dreams, made possible only after the distinction between subjectivity and objectivity had established itself as the

European Journal of Pragmatism and American Philosophy, VIII-2 | 2016 
great epistemological divide among scientists as well as philosophers" (Daston 2008: 99). Peirce himself sensed a Kantian flavour coating Whewell's discussion of the divide between ideas and observations: "Whewell's statement [i.e. that discovery in science consists of ideas drawn from within and facts drawn from without] is Kantian in its form, more Kantian than anybody" (R1274a: 4). Placing 'innate' or 'natural' ideas as guides for observation hides an implicit view that the observation of facts remains an inherently 'dumb' and brute affair in the absence of a separate and higher set of conceptual skills. This is precisely the view of observation that Peirce is trying to overturn by insisting on the historicity and growth of ideas. In a similar vein, stressing the 'innate' and natural character of ideas as guides to observations will not result in rendering observations, in turn, more 'natural' in a strictly reductive biological sense. On the contrary, Peirce seems to be claiming that Whewell's lesson becomes far more effective when the line between (passive) observations and (active) ideas is challenged on historical grounds. When it comes to complex human affairs, 'natural' and 'historical' lay on a continuum, and this is the case not only for the iterative complementarity of ideas and observations, but also for the relevance of this complementarity within Peirce's broader account of the classification of the sciences.

41 It is precisely this historicised and practice-specific notion of observation that Peirce places at the core of his idea of a 'natural' classification of the sciences in R1336, the manuscript that reflects the status of Peirce's classification in the early 1890 s with which I opened this section. When the sciences are classified in respect to the characteristics of their objects," Peirce claims in a crucial passage, "those which depend upon different kinds of observations are better separated and more according to nature than in any other way" (R1336: 7, emphasis mine). Recall that earlier on in the manuscript Peirce presents a differential view of classification: for a classificatory system to be significant, it should contain "as many interesting extra points of distinction as possible" (R1336: 6) between different kinds of sciences. But what exactly determines this difference? A first step could be to tailor classification around the objects of investigation of a particular kind of inquiry: this would also be an intuitive way of justifying the status of a classification as 'natural.' This move, however, would not exhaust the empirical content of a classification of the sciences. For objects themselves depend on the particular respects in which a certain community of practitioner is trained to observe them: practitioners, rather than objects, are the most 'natural' content of a classification of the sciences, and form its very empirical content. Classification is observation-dependent not in the sense of being relative to the whim of particular scientific practitioners (Peirce would reject this approach as a form of nominalism), but because observation, possessing an element of generality, is itself the most 'natural' foundation upon which the order of the sciences can be built.

The idea of 'natural' classification persists in Peirce's system, and is indeed a trait that will be maintained all along, until his 'perennial' 1903 version of the classification of the sciences. But it would be a mistake to consider this as a distinctive and unique feature of Peirce's classification. Nor is the comparison with Whewell's account of how ideas furnish a 'natural' guide to classify the sciences an isolated influence on Peirce. All nineteenthcentury classifiers subscribed to the conviction that a rational organisation of the sciences should be 'natural.' The trend was to model 'natural' on biological taxonomy, a field that had been undergoing a revival at least since the previous century. As Csiszar 
points out, each nineteenth century classifier had his own preferred taxonomer as a point of reference:

Against the nominalism of the Encyclopédistes' Buffon, Comte preferred the functionalist approach to taxonomy of Cuvier, Bentham championed the methods of Linnaeus, while Ampère sang the praises of the Jussieu family's natural method of botanical classification. Each of them believed that their chosen naturalist had finally provided them a method that would make it possible to invent a classification of knowledge that was truly natural. (Csiszar 2010: 383)

For Peirce such a fundamental point of reference was Louis Agassiz, whose lectures he had attended in 1860. The relationship between natural classification and Agassiz's approach to taxonomy is something that Peirce discusses in detail in the 1902 Minute Logic , in a projected chapter entitled "On Science and Natural Classes" (EP2: 115-32). Along with providing important details of the sense in which a classification of the sciences should be 'natural,' this particular piece lends substantial evidence to my contention that Peirce used his classification as a form of 'currency' to enter the broader nineteenthcentury debate on how the sciences should be organised. The chapter starts with a reference to Ernest Cushing Richardson's 1901 Classification. Theoretical and Practical, a work Peirce had reviewed for the Nation at the beginning of 1902 and found theoretically poor, but practically useful. ${ }^{19}$ Richardson's extensive appendix, containing 146 classifications of the sciences alongside to 173 archival systems for indexing subjects, is an illuminating example of the merging of epistemic and bureaucratic motivations behind the impulse toward classification, as outlined by Csiszar (2010: 350). Each of the 146 scientific classifications presented by Richardson, Peirce claims in his chapter on "Science and Natural Classes," aspires to be "the one and true classification" (EP2: 116). But what is meant by a 'natural' class? Peirce notes that many of the previous classifiers have assumed that referring to zoology and botany may be sufficient to justify the metaphysical connotations of their use of the term 'natural.' However, "if botany and zoology must perforce rest upon metaphysics, by all means let this metaphysics be recognised as an explicit branch of those sciences and be treated in a thoroughgoing and scientific manner" (EP2: 116). It is here that Agassiz offers a prime model of 'natural' classification. Peirce does not embrace his system in full - he specifically claims that his classification "was put forward at a somewhat inauspicious moment" (EP2: 128n), so that it was almost born out of date in light of the impact of Darwin's ideas about evolution. Nevertheless, at least Agassiz made his metaphysical commitments clear, explicit, and somewhat 'testable' in contrast to his critics, whose classifications "are saturated with metaphysics in its dangerous form - i.e., the unconscious form" (EP2: 128n).

From Agassiz Peirce borrows two fundamental points. One is the subdivision of science according to categories that Agassiz proposed for the natural world: branches, classes, orders, families, genera and species. A classification should, for Agassiz as well as for Peirce, account for what sort of characters distinguish branches from branches, classes from classes and so on (ibid.). There is then a more fundamental point that Peirce borrows from his former teacher: the notion that natural classifications should offer an arrangement of its objects "according to the ideas from which their existence results" (EP2: 128n, emphasis mine). Once again, ideas creep up in Peirce's discussion of a natural classification, but here Peirce adds an explicitly metaphysical layer to the characterisation of ideas as a criterion for classification that he borrowed from Whewell in the early 1890s. The claim that natural classes owe their existence to ideas, Peirce claims following Agassiz, amounts to stating that natural classes are defined by final causes. Indeed Peirce openly claims that a 
lasting legacy of Agassiz's classification consists precisely in "directing our attention to the supreme importance of bearing in mind the final cause of objects in finding out their own natural classification" (EP2: 129). Much has been written on Peirce's account of final causes (Short 1981; Short 2007; and Pape 1993), and an in-depth exegetic analysis of this particular aspect of his philosophy is well beyond the scope of my discussion. It is important to point out, however, that in this particular context Peirce differentiates clearly final causes from 'purposes.' A purpose is "merely that form of final cause which is most familiar to our experience" (EP2: 120), whereas the meaning of final cause Peirce is advancing with reference to a natural classification of the sciences relates precisely to "objects of [a] class deriving their existence from an idea" (EP2: 123). It is in fact from ideas that the sciences derive their genealogy: just like cellulose affords opportunity for the beauty of a rose, Peirce claims, so ideas afford opportunity for a natural organisation of the sciences (EP2 122). This is a crucial connection that allows Peirce to establish a direct link between a 'natural' classification and science as a living entity and as a pursuit carried out by its practitioners. Peirce expresses this connection in a crucial passage, which presents a distinctive pragmaticist flavour:

What I mean by the idea's conferring existence upon the individual members of the class is that it confers upon them the power of working out results in this world, that it

confers upon them, that is to say, organic existence, or, in one word, life. (EP2: 124)

A natural classification is thus neither the "exudation of living science" (EP2: 129) nor is it the projection of an ideal image of science "such as the classifier hopes may sometime exist" (EP2: 129). Instead, a natural classification of the sciences should afford the living members of the scientific community the opportunity to work out results in the world. This adds to Peirce's classification a generative dimension, which is directly related to its distinctive historicity. The two are complementary angles arising from Peirce's claim that all natural classification is "an attempt at finding the true genesis of the objects classified" (EP2: 127). By genesis Peirce means "not the efficient action which produces the whole by producing the parts, but the final action which produces the parts because they are needed to make the whole" (EP2: 127). Thus construed, classification is at the same time real and ever-evolving: "genesis is production from ideas," and as ideas grow so do our classifications of the sciences. The historicity of Peirce's classification derives precisely from this constant articulation of 'parts' (that is, individual sciences) as they are needed to make the whole of science, in a process that is both prompting practitioners to reflect on how the sciences got where they got, and disclosing questions that still await for a scientific answer.

\section{Peirce's Classification, and the Writing of History}

Along with the writing of R1336, the year 1892 is also the time in which a version of Peirce's classification of the sciences appears as the preface of the first Lowell Lecture in the history of science (R 1274a [fig. 3]). The lectures were commissioned in late 1891, after the geologist and member of the US Geological Survey George Ferdinand Becker recommended Peirce to Augustus Lowell as the ideal person who could cover the subject of science and its history "with so much knowledge and acumen" (W8: ix). Peirce started working on the lectures in February 1892 (W8: lxvii). This also coincides with a draft, dated 13 February 1892 and composed on paper from the Century Club, of a classification of the sciences organised "in their order of generality" (W8: 275 [fig. 4]). The two schemes 
do not present substantial conceptual differences and are themselves variations of the classification that had appeared in the Century Dictionary entry on "Science" a year earlier, in 1891.

Peirce's reflections on how ideas can serve as a guide for a 'natural' classification of the sciences, as outlined in my discussion of R1336 in the previous section, offer a powerful and overlooked commentary to the practical use of his classificatory scheme in the early 1890s. This is especially important in light of the intense historical work that would characterise Peirce's production in those years, and which culminated in 1898 with the drafts for a history of science in one volume for the editors Putnam's Sons. The manuscript for the first Lowell Lecture prefaces Peirce's classification with a somewhat laconic statement: "It will be convenient for the purpose of these lectures to use the classification of the sciences shown in Diagram I" (R1274a [fig. 3]). Peirce does not expand further in this particular manuscript. In W8, the editors of the Peirce Edition Project suggest that a further draft of the first Lowell Lecture ( $R$ 1337) could be viewed as a commentary to the classificatory schemes Peirce developed in 1892 (W8: 447).

\section{Fig.3 R 1274a, Lecture I from Peirce's Lowell Lectures in the History of Science}

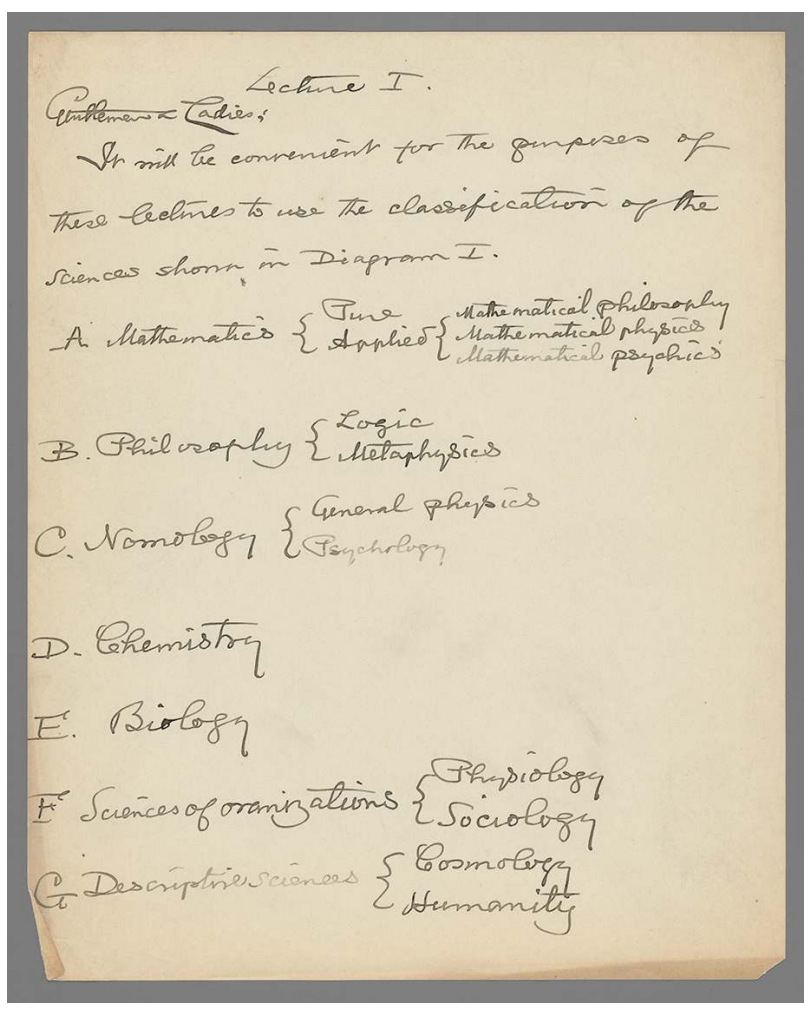

THE HOUGHTON LIBRARY, HARVARD UNIVERSITY 
Fig 4. R1347, The Sciences in their Order of Generality. Reprinted in W8: 275.

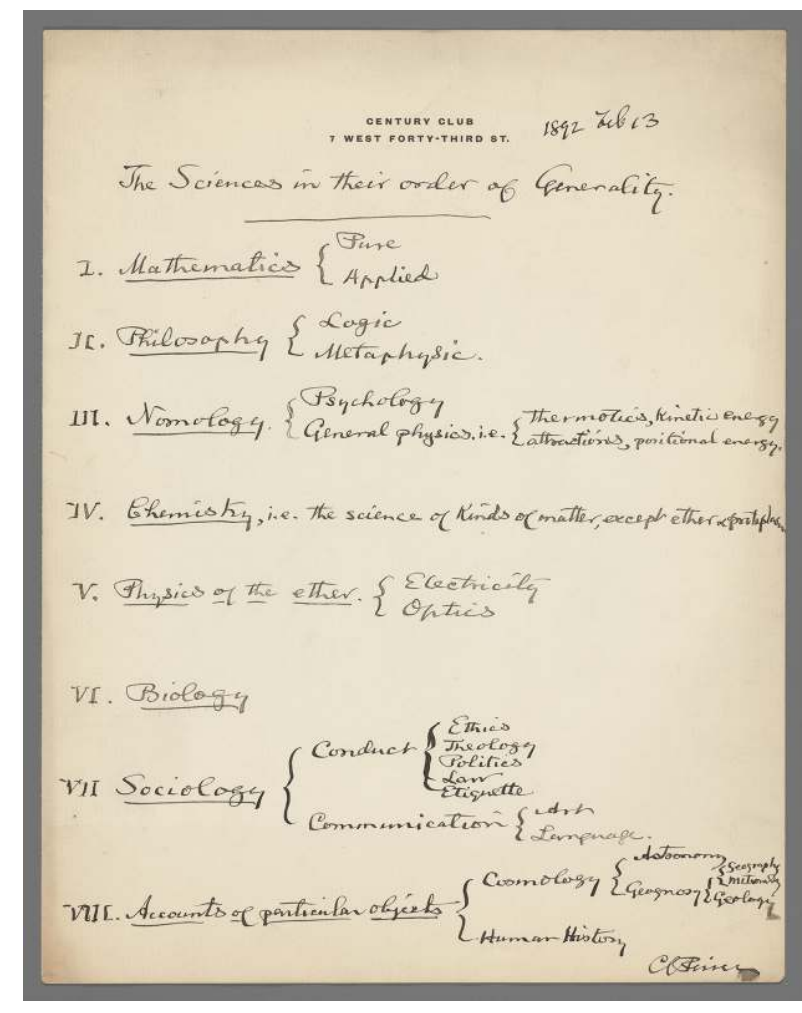

THE HOUgHTON LIBRARY, HARVARD UNIVERSITY

But while the annotations in W8 follow primarily how Peirce justifies the position of each science in his scheme, I would like to draw attention to a contextual explanation that Peirce provides in R1337, and which he sets as the background for the particular organisation of the sciences in his classification: "All science is a development of primitive ideas connected with growth" (R1337: 1, emphasis mine). This is an important qualification, one that brings the lectures on the history of science explicitly in dialogue with the discussion of the classification of the sciences outlined in R1336. The basic distinction Peirce outlines between the sciences, at least in this particular draft, is between the two primitive ideas of self-preservation, guiding the physical sciences, and reproduction, guiding the psychical sciences. "This dichotomy," Peirce continues, "is the most fundamental division of the sciences, Physics the knowledge of things and their mutual forces; Psychics the knowledge of beings and their mutual influences" (R1337: 1). ${ }^{20}$ At a very fundamental level, Peirce is here articulating the insight, developed from Whewell, that ideas offer the most natural principle for a classification of the sciences. He is also beginning to articulate it in accordance to the 'genetic' approach he would delineate more precisely a few years later, in the 1902 Minute Logic: 'genesis is production from ideas' (EP2: 127). Placing the primitive ideas of self-preservation and reproduction as the rationale for his distinction between physical and psychical sciences, Peirce is here once again delineating his classification in continuity with Whewell's historical legacy, and he is explicitly doing so in the context of his historical writings.

A further important question arises from Peirce's use of his classification of the sciences as the preface of his Lowell Lectures. The continuity between Peirce's writings from the early 1890s helps us tracing precise connections as far as the context of his early versions 
of the classification is concerned. But this does not quite explain why he deemed it important to present a classification of the sciences in the opening of his lectures on the history of science in the first place. Here my account departs from the narrow details of Peirce's text to move toward a historiographical hypothesis with broader implications. I have argued in the previous section that one of the ways in which Peirce's classification qualifies as 'natural' lies precisely in its tracing the configuration of various subcommunities of inquirers at a specific point in history. Transposed in the context of historical inquiry - which is exactly how Peirce approaches the history of science in his 1892 Lowell Lectures - this entails that an account of the organisation of the sciences is not construed as a mere leftover of history, emerging only once progress has been accomplished. Instead, Peirce's placing a classification of the sciences at the very beginning of his history is a rhetorical move with a clear epistemological significance, a reminder that the historian's starting point is always a more or less internalised classification of the present state of knowledge, a classification that functions as the entry point and the springboard for the historian's hypotheses about the past. A classification of the sciences as the preface of a history of science is thus also an open invitation to acknowledge that the present is not only the inevitable starting point of any historical inquiry, but also all the historian ultimately has at her/his disposal to begin that investigation in earnest. Rather than a historiographical limitation, however, Peirce's rhetorical gesture has the effect of turning that awareness into a critical, fallibilist tool at the service of the practice of history. As Vincent Colapietro has highlighted, the broader, thick historicity of Peirce's theory of inquiry is itself a powerful conceptual device not to obliterate, but "to establish the present as the meantime, the time between an indefinite past and an equally indefinite future - to secure the present as a segment of time whose relationship to antecedent and subsequent stretches of time makes the present itself, in effect, a sign" (Colapietro 1996: 136). I claim that this view applies equally well to the case of Peirce's classification in the broader context of his historical writings. Caught in the meantime of her/his current classificatory schemes, the historian is not a prisoner of the present, but the responsible holder of a particular critical angle on the past: "Perspectives are not prisons in which we are condemned to dwell in darkness," Colapietro writes, "but truly angles of vision" (Colapietro 1996: 137). What Peirce is providing by prefacing his first lecture on the history of science with a classification of the sciences is precisely his angle of vision, a statement of identity but also an acknowledgment of the responsibility that historians face in investigating the past from the perspective of a present they cannot escape.

My historiographical hypothesis is partly substantiated by a statement that Peirce himself makes, and which can be found in the form of a handwritten annotation in a rather surprising place. Possibly in parallel with his mature formulation of the 'perennial' classification, Peirce revisited his Century Dictionary entry on "Science". His own copy at the Houghton Library contains a long handwritten extract (fig.5), in which Peirce provides an extensive, critical account of how his classification has changed since the publication of the entry in 1891. But while the distinctively trichotomic articulation of his classification clearly starts betraying the use of his categories as a principle to classify the sciences (Atkins 2006), the historiographical significance of his classification, and his emphasis on classification as a product of the present seem to have remained fairly stable. 
Fig. 5 Peirce's annotations to the entry on Science in the Century Dictionary. R 1597: 5396v.

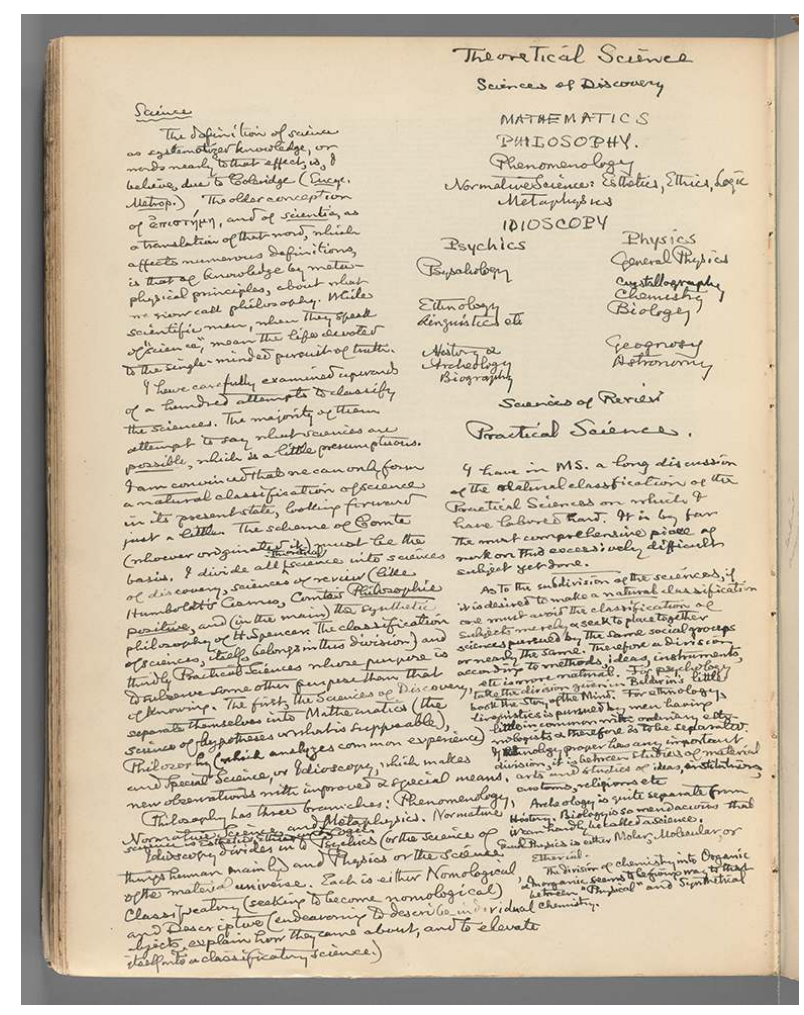

THE HOUGHTON LIBRARY, HARVARD UNIVERSITY

In the annotations, Peirce starts by referring to Coleridge's definition of science in the Encyclopaedia Metropolitana as "systematised knowledge," which he contrasts to the older meaning of episteme or scientia as knowledge by metaphysical principles. The definition offered by Coleridge, who was himself one of the many nineteenth-century classifiers, is what Peirce adopts as it reflects the fact that "scientific men, when they speak of 'science,' mean the life devoted to the single-minded pursuit of the truth" (R1597: 5396v). Here Peirce is setting the ground for his (by then fairly well established) argument that a classification should reflect the practices of its living practitioners. But it is the immediately following paragraph that summarises possibly two decades of Peirce's study of the classification of the sciences, and that conveys the historical and historiographical continuity of his investigation, independently of the changes he made to the logical form of his classification. Peirce states:

I have carefully examined upwards of a hundred attempts to classify the sciences. The majority of them attempt to say what sciences are possible, which is a little presumptuous. I am convinced that we can only form a natural classification of science in its present state, looking forward just a little. The scheme of Comte (whoever originated it) must be the basis. I divide all theoretical science into sciences of discovery, sciences of review (like Humboldt's Cosmos, Comte's Philosophie Positive and (in the main) the synthetic philosophy of $\mathrm{H}$. Spencer. The classification of sciences itself, belongs in this division) and thirdly Practical Sciences whose purpose is to subserve some other purpose than that of knowing. (R1597: 5396v, emphasis mine)

Behind the distinctive trichotomic character of the classification Peirce discusses in his annotations, this statement lends support to the two alternative main lines of inquiry into Peirce's classification I have pursued in this paper. One is the historical claim that 
Peirce used his classification as a sort of 'currency' to enter the broader debate of how the sciences should be organised, and who was entitled to have a say in that debate. As a philosopher as well as a scientific practitioner, Peirce was naturally led toward a minute dissection of the details of that discussion, a discussion in which his own identity was at stake. The careful examination of 'upwards of a hundred attempts to classify the sciences' is at the same time an intellectual pursuit in its own right and an act of responsibility that Peirce performed toward the community of inquirers that formed the very recipient of his philosophy and his science, and without which neither his philosophy nor his practice as a scientist would be possible in the first place.

53 At the same time, Peirce reiterates, perhaps more forcefully, the fact that a natural classification is always a result of being "caught in the meantime," to return to Colapietro's (1996: 136) powerful metaphor: "We can only form a natural classification of science in its present state, looking forward just a little," he claims. This is in line with the second line of inquiry I have pursued in the course of this paper, one that fleshed out how Peirce's classification aimed to furnish an "angle of vision," at the same time serving as the very starting point of inquiry - historical (how science got where it is, why here rather than anywhere else) as well as scientific (what questions are still being generated by the current configuration and evolving relations between the sciences). Drawing on a metaphor that Peirce perhaps would not have endorsed - but one that capitalises on an insight from his close friend William James - his classification of the sciences, reframed in these terms, takes on the function of the historian's specious present: not a "knife edge" to use James' (1983: 574) lucid phrasing - separating an imperfect past from the glorious future of science, but "a saddle back with a breadth of its own," upon which the historian sits perched, looking simultaneously in two directions into time.

\section{Conclusions}

54 In pointing out the fracture between Peirce's 1903 classification of the sciences and his earlier efforts, Peirce scholars miss an important opportunity to follow a range of crucial historical and historiographical insights deriving directly from the contextualisation of such an important part of his philosophy. This seems to be in line with the internalist treatment that Peirce's philosophy has been subject to more broadly, and that has occasionally generated the distorted image, at least outside the immediate realm of Peirce scholarship, of an isolated and genial thinker, whose points of reference were mainly to be found in an extensive and dusty library of classics. Peirce was certainly in part this, but he was also much more. He was a prolific writer immersed in the most lively scientific debates of his time, and his classification of the sciences is evidence of how much his philosophical concerns were shaped by the social context and social debates that surrounded and permeated his philosophical views. While it was not my aim in this paper to offer a complete social history of Peirce's classification of the sciences, I have tried as much as possible to show that there is much to gain from reconciling a sustained historical contextualisation of his work with a careful analysis of its epistemological message.

The account of the early life of Peirce's classification I have presented in this paper has hopefully delineated two possible new avenues of inquiry into Peirce's classification of the sciences. Both revolve around the distinctive historicity of Peirce's project. In recontextualising Peirce's classification as a quintessentially nineteenth-century pursuit, 
I have tried to reconcile a traditionally internalist account of Peirce's classificatory scheme with broader externalist attempts at investigating the debate around the order of the sciences in the nineteenth century. Peirce was a key actor in that debate, with precise views on the coordination of the scientific enterprise, 'natural' classification, and the limitations of alternative classificatory schemes. More importantly, Peirce's sources and his own writings on the subject place him precisely in that transitional area where the bureaucratic impulse driving classification merged with the epistemic quest for a rational organisation of knowledge. Being versed in both fields, Peirce had a great deal to add to the whole enterprise, and as I argued he used his classification as the 'currency' to gain access to the debate.

But the historicity of Peirce's classification emerged also in my investigation of the uses of his scheme as a preface to his historical writings of the 1890s. It is not a coincidence, I argued, that a classification of the sciences, almost with no additional elaboration, was offered to the audience of his Lowell Lectures in the history of science. Here Peirce's main achievement is to show that historical inquiry is by its nature inevitably bound to an inescapable presentism: historians somehow always start from a classification of the sciences as their 'angle of vision.' Interpreting Peirce's work through the framework of historical epistemology has however offered the possibility of turning this inherent limitation into a virtue of historical practice: by prefacing his history with a classification of the sciences Peirce explicitly took responsibility for the inherent contingency that inevitably characterised his own view of the organisation of knowledge, thus turning it into a critical and fallibilist tool.

Peirce's classification of the sciences has still much to offer, beyond what emerged in my initial, tentative overview. Far from being an 'antique bijoux' (to use one of Peirce's most felicitous tongue-in-cheek expressions) to be consigned to the dust of our archives, the vicissitudes of the classification of the sciences in the nineteenth century are one of the richest fields of investigation we have inherited from history. That Peirce was right at the centre of this debate is itself one of the many contingencies of history; that he deliberately decided to have a say in it is an opportunity that Peirce scholars should embrace in full.

\section{BIBLIOGRAPHY}

AMPÈRE André-Marie, (1834), Essai sur la philosophie des sciences (vol. 1), Paris, Bacheliere.

ANDERSON Douglas, (1995), Strands of System. The Philosophy of Charles S. Peirce, West Lafayette, Indiana, Purdue University Press.

ATKINS Kenneth R., (2006), "Restructuring the Sciences: Peirce's Categories and his Classifications of the Sciences," Transactions of the Charles S. Peirce Society, 42, 4, 483-500.

BELL Andrew, (1808), The Madras school; or, Elements of tuition: comprising the analysis of an experiment in education, made at the Male asylum, Madras; with its facts, proofs, and illustrations; to which are added, extracts of sermons preached at Lambeth; a sketch of a national institution for training up the children of 
the poor; and a specimen of the mode of religious instruction at the Royal military asylum, Chelsea, London, Printed by T. Bensley for J. Murray.

Bellucc Francesco, \& Ahti V. PIETARINEN, (2016), "Peirce's Logic," The Internet Encyclopaedia of Philosophy, Available at [iep.utm.edu/peir-log/].

Bentham Jeremy, (1983 [1817]), Chrestomathia, ed. M. J. Smith \& W. H. Burston, Oxford, Clarendon Press.

BONNEUIL Christophe, (2002), "The Manufacture of Species. Kew Gardens, the Empire, and the Standardisation of Taxonomic Practice in Late Nineteenth-Century Botany," in Marie-Nöelle Bourguet, Christian Licoppe \& Otto Sibum, (eds.), Instruments, Travel and Science. Itineraries of Precision from the Seventeenth to the Twentieth Century, New York and London, Routledge, 189-215. BOURDEAu Michel, (2015), “Auguste Comte,” The Stanford Encyclopedia of Philosophy (Winter 2015 Edition), Edward N. Zalta (ed.), URL = [plato.stanford.edu/archives/win2015/entries/comte/ ].

COLAPIETRO Vincent, (1996), “The Ground of Semiosis: An Implied Theory of Perspectival Realism?," in Vincent Colapietro \& Thomas Olshewski (eds.), Peirce's Doctrine of Signs, Berlin and New York, Mouton de Gruyter, 129-40.

COLAPIETRO Vincent, (1998) "Entangling Alliances and Critical Traditions: Reclaiming the Possibility of Critique," Journal of Speculative Philosophy, 12, 2, 114-33.

COMTE Auguste, (1853), The Positive Philosophy of Auguste Comte, (2 vols.) transl. Harriett Martineau, London, J. Chapman.

CSISZAR Alex, (2010), Broken Pieces of Fact: The Scientific Periodical and the Politics of Search in Nineteenth-Century France and Britain, PhD Thesis, Cambridge, Mass., Harvard University.

CSISZAR Alex, (2013), "Bibliography as Anthropometry: Dreaming Scientific Order at the Fin De Siècle," Library Trends, 62, 2, 442-55.

DASTON Lorraine, (2008), “On Scientific Observation,” ISIS, 99, 1, 97-110.

DASTON Lorraine, \& Peter GALISON, (2009), "Scientific Coordination as Ethos and Epistemology," in Helmar Schramm, Ludger Schwarte \& Jan Lazardzig (eds.), Instruments in Art and Science, Berlin and New York, De Gruyter, 296-333.

DASTON Lorraine, \& Elizabeth LUNBECK, (eds.), (2011), Histories of Scientific Observation, Chicago, University of Chicago Press.

DE WAAL Cornelis, (2005), “Why Metaphysics Needs Logic and Mathematics Doesn't: Mathematics, Logic, and Metaphysics in Peirce's Classification of the Sciences," Transactions of the Charles S. Peirce Society, 41, 2, 283-97.

DOLBY Robert, (1997), "Classification of the Sciences: the Nineteenth Century Tradition," in Roy F. Ellen \& David Reason (eds.), Classifications in their Social Context, London, Academic Press, 167-93.

EISEN Sydney, (1967), "Herbert Spencer and the Spectre of Comte," The Journal of British Studies, 7, 1, 48-67.

FISCH Menachem, \& Simon SCHAFFER, (eds.), (1991), William Whewell: A Composite Portrait, Oxford, Clarendon Press.

GALISON Peter, (2003), Einstein's Clocks and Poincaré's Maps: Empires of Time, New York, W. W. Norton. 
HAACK Susan, (2007), “The Legitimacy of Metaphysics: Kant's Legacy to Peirce and Peirce's to Philosophy Today," Polish Journal of Philosophy, vol. 1, 29-43

HANSON Norwood R., (1972 [1958]), Patterns of Discovery, Cambridge, Cambridge University Press.

ITZKIN Elissa, (1978), “Bentham's Chrestomathia: Utilitarian Legacy to English Education,” Journal of the History of Ideas, 39, 2, 303-16.

JAMES William, (1983 [1890]), The Principles of Psychology, Cambridge, Mass., Harvard University Press.

KEDROV Bonifatii, (1964), “The History of Classification of the Sciences," Organon, 165-85.

KENT Beverly, (1987), Charles S. Peirce: Logic and the Classification of the Sciences, Kingston and Montreal, McGill-Queen's University Press.

LAUDAN Larry, (1971), “Towards a Reassessment of Comte's 'Methode Positive'," Philosophy of Science, 38, 1, 35-53.

LEGG Cathy, (2014), "Logic, Ethics and the Ethics of Logic," in T. Thellefsen, \& B. Sorensen (eds.), Charles Sanders Peirce in His Own Words: 100 Years of Semiotics, Communication and Cognition (vol. 14), Berlin,De Gruyter, 271-8.

LUND Matthew, (2010), N. R. Hanson. Observation, Discovery and Scientific Change, Amherst and New York, Humanity Books.

NOVICK Peter, (1988), That Noble Dream: The Objectivity Question and the American Historical Profession, Cambridge, Cambridge University Press.

PAPE Helmut, (1993), "Final Causality in Peirce's Semiotic and His Classification of the Sciences," Transactions of the Charles S. Peirce's Society 29, 581-607.

PEIRCE Charles S., (1931-8/1958), Collected Papers (8 vols.), C. Hartshorne, A. Burks \& P. Weiss (eds.), Cambridge, Mass., Harvard University Press.

PEIRCE Charles S., (1979), Contributions to the Nation, vol. 3, Kenneth Laine Ketner \& James Edward Cook (eds.), Lubbock, Texas Tech Press.

PEIRCE Charles S., (1992-98), The Essential Peirce: Selected Philosophical Writings (2 vols.), N. Houser \& C. Kloesel (eds.) (vol. 1) and The Peirce Edition Project (vol. 2), Bloomington, Indiana University Press.

PEIRCE Charles S., (2010), Writings of Charles S. Peirce, vol. 8, ed. by the Peirce Edition Project, Bloomington and Indianapolis, Indiana University Press.

PICKERING Mary, (1993), Auguste Comte: An Intellectual Biography (vol. 1), Cambridge, Cambridge University Press.

RICHARDSON Cushing Ernest, (1901), Classification: Theoretical and Practical, New York, Charles Scribner's Sons.

SARTON George, (1920), “Herbert Spencer 1820-1903," ISIS, 3, 3, 375-90.

SCHAFFER Simon, (1992), "Late Victorian Metrology and its Instrumentation. A Manufacture of Ohms," in Robert Bud \& Susan E. Cozzens (eds.), Invisible Connections. Instruments, Institutions and Science, Washington, Spie Optical Engineering Press, 23-56.

SCHAFFER Simon, (1997), "Metrology, Metrication and Victorian Values," in Bernhard Lightman (ed.), Victorian Science in Context, Chicago and London, University of Chicago Press, 438-74. 
SCHAFFER Simon, (2013), “How Disciplines Look," in Andrew Barry \& Georgina Born (eds.), Interdisciplinarity. Reconfigurations of the Social and Natural Sciences, London, Routledge, 57-81.

SEKULA Allan, (1986), “The Body and the Archive," October, 39, 3-64.

SHORT Thomas L., (1981), "Peirce's Concept of Final Causation," Transactions of the Charles S. Peirce's Society, 17, 369-82.

SHORT Thomas L., (2007), Peirce's Theory of Signs, Cambridge, Cambridge University Press.

SNYDER Laura J., (2012), “William Whewell,” The Stanford Encyclopedia of Philosophy (Winter 2012 Edition), Edward N. Zalta (ed.), URL (last accessed on 31/10/2016) [plato.stanford.edu/archives/ win2012/entries/whewell/].

SPENCER Herbert, (1864), The Classification of the Sciences, to Which are Added Reasons for Dissenting from the Philosophy of M. Comte, New York, D. Appleton and Company.

SPENCER Herbert, (1904), An Autobiography, vol. 2, New York, D. Appleton and Company.

TRESCH John, (2012), The Romantic Machine, Chicago and London, Chicago University Press.

VIOLA Tullio, (2012), "Pragmatism, Bistable Images and the Serpentine Line," in F. Engel, M. Queisner \& T. Viola (eds.), Das Bildnerische Denken: Charles S. Peirce, Berlin, Academie Verlag, $115-34$.

WHEWELl William, (1834), “On the Connexion of the Sciences," Quarterly Review 51 (March), 54-68. WHEWELL William, (1847), The Philosophy of the Inductive Sciences, Founded Upon Their History, vol. 2, London, John W. Parker.

WHEWELL William, (1857 [1837]), History of the Inductive Sciences, from the Earliest to the Present Time, 3rd Edition, in two volumes, London, John W. Parker.

YEO Richard, (1993), Defining Science. William Whewell, Natural Knowledge and Public Debate in Victorian Britain, Cambridge, Cambridge University Press.

\section{NOTES}

1. The nineteenth century was a century of standardisation, which ranged from units of measurement (Schaffer 1992 and 1998) to taxonomic practices (Bonneuil 2002) to time (Galison 2003).

2. Two frequently cited, albeit rather outdated, sources on this particular issue are Dolby 1997, which views the emergence of classifications as distinctive of the systematic scientific spirit of the nineteenth century, and Kedrov 1964, which traces the origins of the trend toward classification in dialectical materialism.

3. It is in Bentham's Chrestomathia that the terms coenoscopy and idioscopy appear, terms that were used by Peirce in his own classification of the sciences to refer respectively to philosophy and the special sciences.

4. As Simon Schaffer notes, Bentham's Chrestomathia is one of the first texts in which 'technology' is used in its modern sense "as the aggregate body of the several sorts of manual operations directed to the purpose of art" (Schaffer 2013: 66).

5. On Bell's "Madras System," as a distinctively colonial, as well as industrial, educational pursuit see Schaffer (2013: 68ff).

6. Whewell introduced the term in a discourse presented at the 1833 meeting of the British Association. See Yeo (1993: 110-1). 
7. For a wide-ranging account of Whewell's intellectual engagement in the cultural, theological and scientific climate of the Victorian period see Fisch \& Schaffer 1991.

8. A standard complete translation of Comte's works does not exist at present. In what follows, I will cite from Harriette Martineau's (condensed) English translation.

9. On the relationship (or lack thereof!) between Comte's positivism and twentieth-century positivism see Laudan 1971; Tresch (2012, esp. 255-6); and Bourdeau 2015.

10. An important clarification is that, for Comte, different sciences may be at different stages of development at a given time in history. Thus, for example, astronomy was a prime case of a science which had firmly reached the positive stage in Comte's time, while sociology, being the youngest in his series, was still on its way to becoming fully 'positive.'

11. Spencer insisted that he was barely aware of Comte's works at least until as late as 1852 , however some commentators have advanced the hypothesis that he was more familiar with Comte's writings than he claimed to be, primarily via George Eliot and George Henry Lewes, both strong admirers of Comte. See Eisen (1967: 48-9).

12. Kent notes that Peirce's classifications start at least as early as 1866 , although she reconstructs many of his early schemes from the text as they were not presented in a tabular form (Kent 1987: 90ff). In the course of my discussion, I will prioritise tabular or diagrammatic arrangements of Peirce's classification. The PEP now marks R1347 (1892) as 'his most mature diagrammatic development of disciplinary classification,' as well as 'a datable and significant milestone in the development of Peirce's classification of the sciences' (W8. 646). As far less work has been produced on Peirce's classifications of the 1890s, and as these classifications interestingly relate to Peirce's works on the history of science, in what follows I will use that particular decade as the starting point of my discussion.

13. That Peirce disagreed with Spencer's philosophy on broader grounds is evident, for example, from his 1891 review of his Essays, Scientific, Political, and Speculative (W8: 242-4).

14. The text of the article is a broader rejoinder to Carus' comments on Peirce's architectonic and his account of chance, as exposed in his Monist Metaphysical Series (1891-1892).

15. The relationship between Hanson and Peirce, especially on the issue of observation, deserves a discussion of its own, which is beyond the scope of this article (see Lund 2010: Ch. 3) for a productive attempt in this direction). At a basic level, one of the possible criticisms that can be made to Hanson's approach is that, despite its standing out as a pioneering attempt at vindicating observation, it still relegates it to the realm of brute, uneducated perception (hence the role of theory as an indispensable framework to enable interpretation). A criticism along these lines has been proposed by Daston 2008 and Daston \& Lunbeck 2011. On the other hand, Hanson's emphasis on seeing not merely amounting to the "having of a visual experience," but also to "the way in which that experience is had" (Hanson 1972: 15) seems to suggest a far more nuanced stance, and one that is much closer to Peirce's.

16. For the sake of simplicity, here I am only discussing Peirce's view of observation, however it must be pointed out that his account of observation would later converge into his theory of perception, to the point that the two are extremely difficult to detangle. Peirce's account of perceptual judgments, and more generally of the inferential nature of perception (which for Peirce is inherently abductive, and which he models on sight), is fully articulated in his 1903 Lectures on Pragmatism. There Peirce exposes his three cotary propositions: 1) nihil est in intellectu quin prius non fuerit in sensu, which Peirce reads as "in perceptual judgments (in sensu) we find the source of a sign's meaning (intellectus)"; 2) "perceptual judgments contain general elements"; 3) "perceptual judgments are to be regarded as extreme cases of abductive inferences" (EP2, 226-7). On the relation between observation and perception in Peirce see Viola (2012: 117-22).

17. Whewell did not dismiss Bacon per se - indeed he considered his work as a continuation of the Baconian project. He did think that Baconian induction should be revived and 'renovated' - 
and indeed one of the volumes of the third edition of the Philosophy of the Inductive Sciences bears the title of "Novum Organon Renovatum," with explicit reference to Bacon. See Snyder 2012.

18. Here I am presenting Peirce's interpretation of Whewell's views, however it is open to question whether Whewell's conception of ideas was really as intuitionist as Peirce presents it. Laura Snyder (2012), for example, stresses that for Whewell "fundamental ideas and conceptions are provided by our minds, but they cannot be used in their innate form." Instead, they have to be subject to a process of 'unfolding,' which whewell referred to as "the explication of conceptions" (Snyder 2012).

19. In his review, Peirce reproaches Richardson for having forgotten his own entry on "Science" in the Century Dictionary as an additional example of classification of the sciences. See (CN 3: 62).

20. The draft continues with a discussion of the standard form of Peirce's classification of the sciences: thus mathematics is considered the first and widest branch of science, followed by philosophy (only divided into logic and metaphysics at that point). The third order of science is occupied by nomology, divided into physical and psychical. Chemistry occupies the fourth order of science, followed by the physics of the ether as the fifth order, and biology as the sixth. The seventh order of science features sociology and only in the eight order Peirce places "the sciences which treat of individual objects or collections of objects" (R1337: 8), such as cosmology and history.

\section{ABSTRACTS}

The classification of the sciences is one of the most discussed and analysed aspects of Peirce's corpus of work. I propose that Peirce's attempt at systematising the sciences is characterised by a distinctive historicity, which I construe in two complementary senses. First, I investigate Peirce's classification as part of a broader nineteenth-century move toward classifying the sciences, a move that was at the same time motivated by social and epistemological goals. I claim that this re-contextualisation adds an entirely new layer to the otherwise distinctively internalist readings of Peirce's classification. I then look at how Peirce's scheme, especially in the form it displayed in the early 1890s, relates to his own historical writings, particularly his history of science. Looking at Peirce as a historical actor in his own right through the lens of his classification, I claim, is indispensable to understand the contemporary relevance of his contributions to the history and historiography of the sciences.

\section{AUTHOR}

\section{CHIARA AMBROSIO}

University College London

c.ambrosio[at]ucl.ac.uk 